\title{
Meaningful managerial action planning: The financial component
}

\author{
J.G. Kotzé
}

School of Business Leadership, University of South Africa, Pretoria

An innovative orientation is a highly desirable characteristic of senior-middle and top management teams in business organizations. The formalized expression of such entrepreneurial flair may be developed in the form of action plans. Such plans conslst of five elements, of which one, namely the financial component, is of prime importance. Three categories of action plans are distinguished and the evaluation of the anticipated financial im. pact of action plans within each category discussed. Finally, the integration of the anticipated financial results of action plans in the formal long- and shortterm plans of an organization is described

S. Afr. J. Bus. Mgmt. 1963, 14: $156-160$

'n Innoverende oriéntasie is 'n baie gesogte eienskap van senior. middel- en topbestuurspanne in 'n bedryfsorganisasie. Die for. malisering van sodanige entrepreneurskap mag in die vorm van aksieplanne geskied. Hierdie planne bestaan uit vyf elemente, waarvan een, naamlik die finansiële komponent, van die allergrootste belang is. Drie kategoriee van aksieplanne word onderskei en die evaluasie van die verwagte finansiěle impak van aksieplanne wat binne elke kategorie ressorteer, bespreek. Laastens word die integrasie van die verwagte finansiële resultate van aksieplanne in die formele lang. en korttermynplanne van 'n organisasie beskryf.

S.Afr. Tydskr. Bedryfsl. 1963, 14: $156-160$

\section{J.G. Kot2}

School of Business Leadership, University of South Africa,

P.O. Box 392, Pretoria 0001, Republic of South Africa

\section{Introduction}

In recent years several management theorists ${ }^{1,2,3}$ have emphasized the importance of innovative entrepreneurial action thinking in any organization. Although such an orientation is tacitly expected from every member of an organization, it is rapidly becoming a formal requirement of all senior-middleand top-managerial positions. The intellectual, entrepreneurial ability of these executives to initiate present action aimed at capitalizing on predicted favourable trends and to minimize the impact of unfavourable trends; to improve on an existing situation, whether favourable or unfavourable; and to timeously adjust organizational operations to deal with unanticipated environmental changes constitute important elements of their performance.

Undirected entrepreneurial action can, obviously, be dysfunctional. The process should, therefore, be continuously triggered by and directed and co-ordinated within a formal framework of planning and control systems. For an exposition of such a framework, the interested reader is referred to Schutte. ${ }^{4}$

This article illustrates the formal expression of innovation action in the format of an action plan. One element, namely the financial component, is analysed in greater detail and the integration of the anticipated financial results of approved action plans in the formal long- and short-term plans of the organization is described.

\section{Format of action plans}

An action plan should encompass the following five major elements:

- the objective of the planned action should be stated in operational terms;

- the successive steps to be taken to ensure achievement of the objective should be detailed;

- the responsibility structure involved in the execution of the steps must be stated;

- the target dates for the completion of every step must be determined;

- the estimated financial impact of the proposed action must be evaluated. ${ }^{s}$

These elements can be combined in the general format as depicted in Table 1.

The financial component is vitally important as this instills the discipline of thinking a proposed course of action through in a logical sequence. It is, also, normally the most difficult element in formal action planning. This component is therefore analysed in greater detail in the remainder of this article.

This analysis can be carried through more meaningfully in 
Table 1

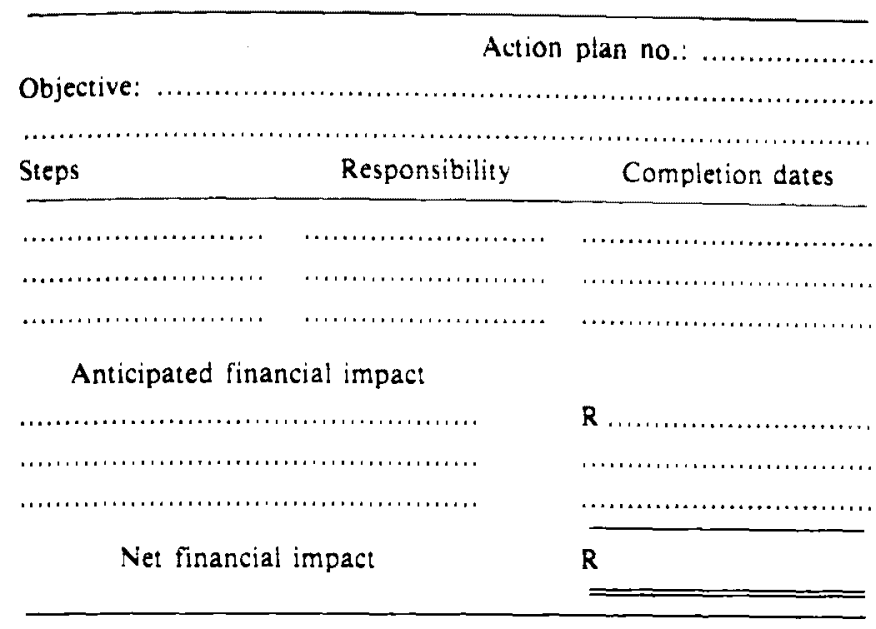

a framework of the major classes of action plans. Accordingly, a classification of the different types of action plans which might be encountered in an organization is developed in the next section.

\section{Classification of action plans}

The objective of action plans may be to improve on the anticipated results of the financial year in which the entrepreneurial action is being instituted. In this case, the predicted financial impact of the action plan is not expected to extend beyond the financial year end. The anticipated financial impact of other action plans may affect the results of several future financial periods. Some action plans require an operating expenditure while others necessitate a capital investment.

In Table 2, action plans are classified utilizing the concepts of short versus long term and operating expenditure versus capital investment.

\section{Table 2}

\begin{tabular}{lcc}
\hline & Operating expenditure & Capital investment \\
\hline Present financial year & A & C \\
$\begin{array}{l}\text { Present and future } \\
\text { financial years }\end{array}$ & B & \\
\hline
\end{tabular}

\section{Category A}

Action plans in this category normally require a relatively small operating expenditure with the objective of achieving some level of cost savings and/or some increase in revenue in the remaining portion of the financial year.

The approval level of these action plans is usually relatively low in the organizational hierarchy.

The extent of financial analysis required for the approval decision is limited.

\section{Category B}

Action plans in this category normally require relatively large operating expenditures with the objective of achieving cost savings and/or increases in revenue in the remaining portion of the financial year as well as in succeeding financial years.

The approval level of these action plans is typically higher in the hierarchy than the Category $\mathrm{A}$ levels due to the larger amounts of expense involved.

As the financial impact is expected to extend over several financial years, more sophisticated financial analysis than in the case of the Category A pians is required for the approval decision.

\section{Category C}

Action plans in this category require a capital investment outlay. Additional land, buildings, equipment and/or vehicles have to be obtained to meet the objectives of these plans. The amounts required might be relatively small (for example, the purchase of a delivery vehicle) or quite large (for example, extensions to productive capacity).

The anticipated financial impact of action plans in this category always extend over more than one financial year. The approval level of the majority of action plans in this category is usually high in the organizational hierarchy. In the case of major capital investments, the approval level is usually the board of directors.

Very comprehensive financial analysis is usually required for Category $\mathrm{C}$ action plan proposals.

The quantification of the expected financial results of these three classes of action plans may differ in the degree of detail required as well as in the appropriate method of analysis to be employed.

\section{Quantifying the anticipated financial result}

In Table 3, an action pian developed in an automotive component company, ${ }^{6}$ illustrates the required format of a Category $A$ action plan.

The financial analysis required is a simple accounting calculation of the incremental increase/decrease in cash inflow and the incremental increase/decrease in cash outflow resulting from the successful implementation of the action programme during the remainder of the financial year.

Table 3 Objective: To increase the marginal con. tribution of sales through selective price increases by R40 000 to the end of the financial year

\begin{tabular}{|c|c|c|}
\hline Steps & By whom & By when \\
\hline $\begin{array}{l}\text { - Issue instructions to market } \\
\text { research }\end{array}$ & $\begin{array}{l}\text { Marketing manager } \\
\text { D. McDuff }\end{array}$ & 30 June \\
\hline $\begin{array}{l}\text { - Test the market for elasticity of } \\
\text { demand at increased prices of } \\
\text { product A BC and altematives, } \\
\text { D \& E }\end{array}$ & $\begin{array}{c}\text { Market research } \\
\text { B. Smith }\end{array}$ & $\begin{array}{l}31 \text { July - within } \\
4 \text { weeks }\end{array}$ \\
\hline $\begin{array}{l}\text { - Analyse results, select products } \\
\text { for increase and implement } \\
\text { increase }\end{array}$ & $\begin{array}{l}\text { Marketing manager } \\
\text { D. McDuff }\end{array}$ & $\begin{array}{c}7 \text { August - within } \\
1 \text { week }\end{array}$ \\
\hline \multicolumn{3}{|c|}{ Profit impact } \\
\hline
\end{tabular}

Increased marginal contribution

Product A $10 \%$ increase in turnover $80000 \quad$ R8 000

Product B $6 \%$ increase in turnover $300000 \quad$ R18 000

Product $C \quad 4 \%$ increase in turnover $400000 \quad$ R 16000

$\mathrm{R42000}$

Less additional promotion in support of Produet B $(2000)$

840000

$==$

In Table 4, an action plan developed in an electrical appliance manufacturing corr. es as an illustration of 
Table 4 Objective: Introduce low manufacturing. cost cooker to combat imports by November 1981. Dealer price to be R250,00. Features as per schedule AWHK/LAB 1019. To achieve budgeted increase in sales $15 \%$ p.a.

\begin{tabular}{|c|c|c|c|c|}
\hline & Programme: & Facility & Responsible & Date \\
\hline (a) & $\begin{array}{l}\text { Finalize marketing } \\
\text { features price and size }\end{array}$ & MKTG. & D.J.S. & Complete \\
\hline (b) & $\begin{array}{l}\text { Tentative costing of } \\
\text { mock-up }\end{array}$ & COSTING & M.W.G.S. & 30.10 .80 \\
\hline (c) & $\begin{array}{l}\text { Working prototype for } \\
\text { testing }\end{array}$ & ENG. & F.M.C. & 01.11 .80 \\
\hline (d) & $\begin{array}{l}\text { Engineering drawings } \\
\text { complete }\end{array}$ & ENG. & F.M.C. & 10.12 .80 \\
\hline (e) & Final costing complete & COSTING & M.W.G.S. & 03.01 .81 \\
\hline (f) & $\begin{array}{l}\text { Capital required signed } \\
\text { off }\end{array}$ & FINANCE & T.B. & 15.01 .81 \\
\hline (g) & $\begin{array}{l}\text { Tooling and tool trials } \\
\text { complete }\end{array}$ & MNFG. & H.S.G. & 15.07 .81 \\
\hline (h) & $\begin{array}{l}\text { Pre-production pilot } \\
\text { run complete }\end{array}$ & MNFG. & H.S.G. & 15.08 .81 \\
\hline (i) & $\begin{array}{l}\text { Sample to marketing for } \\
\text { advertising copy and } \\
\text { sales literature }\end{array}$ & ENG. & F.M.C. & 01.09 .81 \\
\hline (j) & $\begin{array}{l}\text { Service specifications } \\
\text { and catalogues complete } \\
\text { Job } 1 \text { production }\end{array}$ & $\begin{array}{c}\text { SERVICE } \\
\text { MNFC. }\end{array}$ & $\begin{array}{l}\text { N.R.W. } \\
\text { H.S.G. }\end{array}$ & $\begin{array}{l}01.10 .81 \\
01.11 .81\end{array}$ \\
\hline (1) & $\begin{array}{l}\text { Distribution to regional } \\
\text { warehouses }\end{array}$ & DISTR(N) & M.L.M. & 23.11 .81 \\
\hline
\end{tabular}

Using cost savings as previously tabled which result in $10 \%$ saving in variable costs and allowing $5 \%$ reduction in sales prices, profit impact for 12 months as follows:

\begin{tabular}{lccc} 
& Year 1 & Year 2 & Year 3 \\
\cline { 2 - 3 } $\begin{array}{l}\text { Increased sales contribu- } \\
\text { tion }\end{array}$ & 100 & 130 & 170 \\
$\begin{array}{l}\text { Variable manufacturing } \\
\text { expenses }\end{array}$ & 72,3 & 96,5 & 128 \\
\hline $\begin{array}{l}\text { Factory var. margin } \\
\text { Warranty \& distribution }\end{array}$ & 27,7 & 33,5 & 42 \\
$\quad$ Variable margin & 6,9 & 7,5 & 9 \\
\hline Factory fixed expenses & 9,8 & 26 & 33 \\
$\quad$ Net profit: & 11,0 & 11 & 13 \\
\hline
\end{tabular}

the required format of a Category B action plan.

The financial impact analysis extends over more than one financial year. The probable impact of inflation, accordingly, has to be considered. In the illustrative action plan, it is tacitly assumed that inflation will have exactly the same impact on all the major items of cash inflow as well as cash outflow. If this is not the case, the predicted inflow and outflow calculations for every financial year have to be adjusted to reflect the anticipated impact of inflation.

Finally, in Table 5, a hypothetical action plan serves as illustration of the required format of a Category $C$ action plan.

The financial analysis required for Category $\mathrm{C}$ action plans necessitates careful consideration of the following factors:

- the time value of money;

- the discounting factor to be used in the present value calculations;

- the predicted salvage value of any capital assets;
- the impact on the existing working capital level of the proposed capital acquisition and the subsequent recovery of the wolning capital at the end of the economic life of the capital asset;

- the impact of inflation on the anticipated cash inflows and outflows;

- the taxation effect of the proposed capital acquisition in the form of initial and investment allowances; the depreciation tax allowance and the tax effect of the predicted salvage value of the capital asset.

For a detailed discussion of the above matters, the interested reader is referred to Clark, Hindelang and Pritchard. ${ }^{8}$

\section{Integration into the financial planning and control processes}

The large, well-managed business organization will probably use all or most of the following formal planning and control documents:

- a strategic plan;

- a capital budget;

- a long range business plan: this document normally takes the form of an operating budget which covers a future period of three to five financial years;

- a short range business plan: this document is normally the annual operating budget;

- a planning 'bridge of performance' statement;

- a control 'bridge of performance' statement.'

The anticipated financial results of the three categories of action plans will be reflected in Table 6 .

Category $\mathrm{A}$ action plans are developed on a recurring basis with the objective of improving the anticipated financial results of the current accounting period. The development of these action plans is a reaction to almost continuous pressure to adjust favourably to changing circumstances. These are, accordingly, 'control' or 'replanning' action plans and the anticipated financial impact does not affect any formal planning or control document, except the control bridge of performance statement which should be developed on a regular (monthly or quarterly) basis. This document is, in essence, an updated forecast of year-end results incorporating the anticipated results of approved 'replanning' action plans.

Category B action plans are developed on the same basis as Category A plans but the anticipated financial results will affect multiple accounting periods. They are, therefore, analysed and allocated to these periods as follows: The total impact of such an action plan is taken up in the long range business plan; the forecasted impact on the financial year following the accounting period in which such an action plan is developed, is included in the short range business plan as well as in the planning bridge of performance statement. (The latter is the most important working paper from which the short range business plan is developed.) Finally, any impact anticipated in the year in which the action plan is developed is, as is the case with Category B plans, included in the control bridge of performance statement.

The integration of Category $\mathrm{C}$ action plans differs from that of Categor B in as much as the entire cash inflow and outflow associated with the action plan are also included in the capital budget of the organization. Furthermore, the strategic plan of the organization is affected as well. In the formulation of a strategy, as far as the financial component is concerned, two stages may be identified. The allocation of financial resources and the releasing of such resources. The allocation of resources required for an approved strategy is taken up in the format 
Table 5 Objective: To extend productive capacity by the purchasing of a new grinding machine, No. Mx 1930, with an expected economic life of 5 years and costing R100 000

$\begin{array}{lccc} & \text { Responsibility } & \text { Completion dates } \\ \text { a. Prepare memorandum for board approval } & \text { Industrial Engineer } & 31.03 .1983 \\ \text { b. Obtain board approval } & & \text { Operations Manager } \\ \text { c. Supply specification to procurement division } & & \text { Industrial Engineer } & \mathbf{3 0 . 0 4 . 1 9 8 3} \\ \text { d. Oversee installation of machine } & \text { Engineering Division } & 30.05 .1983 \\ \text { c. Commissioning of machine } & \text { Supplier } & \mathbf{0 4 . 0 7 . 1 9 8 3}\end{array}$

Anticipated financial impact

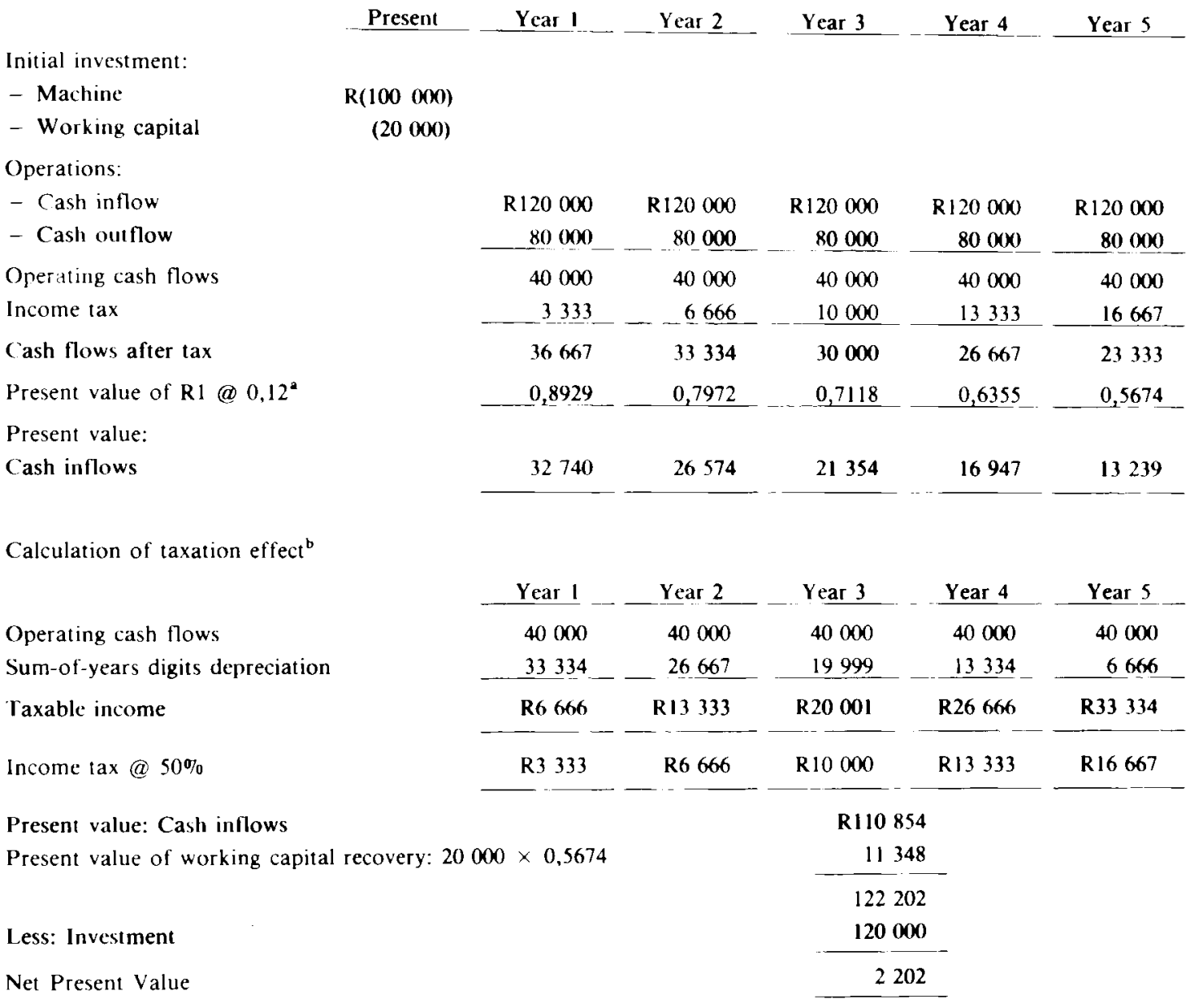

${ }^{\text {"A }} 12 \%$ investment hurdle rate (cost of capital) is assumed.

"It is assumed that this investment does not qualify for initial and investment tax allowances, and that the machine has no salvage value.

Table 6 Action plan impacts in the planning and control process

\begin{tabular}{|c|c|c|c|}
\hline & Category A & Category B & Category C \\
\hline Strategic plan & & & $\mathrm{x}$ \\
\hline Capital budget & & & $\mathrm{x}$ \\
\hline Business plan: long range & & $\mathrm{x}$ & $\mathrm{x}$ \\
\hline Business plan: short range & & $\mathbf{x}$ & $\mathbf{x}$ \\
\hline $\begin{array}{l}\text { Bridge of performance: } \\
\text { planning }\end{array}$ & & $\mathbf{X}$ & $x$ \\
\hline $\begin{array}{l}\text { Bridge of performance: } \\
\text { control }\end{array}$ & $x$ & $\mathbf{x}$ & $\mathbf{x}$ \\
\hline
\end{tabular}

of an action plan and forms part of the strategic plan. The second stage, the releasing of resources, is implemented on the strength of a financial analysis as illustrated in Table 5.

\section{Conclusion}

In this article an extremely important prerequisite to the success of a business organization, namely, directed entrepreneurial flair, has been defined and formalized in the format of an action plan. One component of such a plan - the anticipated financial impact - was analysed and described in greater detail.

Practical results in organizations which have implemented the concept of formalized entrepreneurial action as an integral element of excellent performance on the senior-middle to top management levels, attest to the value of this orientation.

\section{References}

1. Argenti, J. Systematic corporate planning. Middlesex: Nelson, 1979 
2. Schutte, F.G. Budgetary Control systems for the eighties, J. Gen. Manage., vol.5, no.3, 1980.

3. Watson, C.E. Results-oriented managing. Reading, Massachusetts: Addison-Wesley, 1981.

4. Schutte, op. cit.

S. Wilson, S.R. \& Tomb, J.O. Improving profits through integrated planning and control. New Jersey, Englewood Cliffs: PrenticeHall, 1970.
6. Schutte, op. cit.

7. Cason, F. (No title). Pretoria: University of South Africa, School of Business Leadership, Advanced executive programme, 1981 (Directive Management script).

8. Clark, J.J., Hindelang, T.J. \& Pritchard, R.E. Capital Budgeting: Planning and control of capital expenditures. New Jersey, Englewood Cliffs: Prentice-Hal, 1979.

9. See Schutte, 1980, op. cit. (Planning \& Control 'working papers'). 